\title{
REAL-TIME DATA
}

AND FISCAL POLICY

ANALYSIS

A SURVEY OF THE LITERATURE 


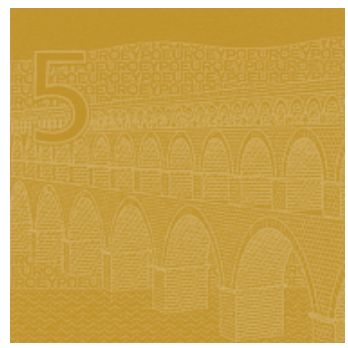

\title{
WORKING PAPER SERIES NO |408 / DECEMBER 20II
}

\author{
REAL-TIME DATA AND \\ FISCAL POLICY ANALYSIS
}

A SURVEY OF THE LITERATURE'

\author{
by Jacopo Cimadomo²
}
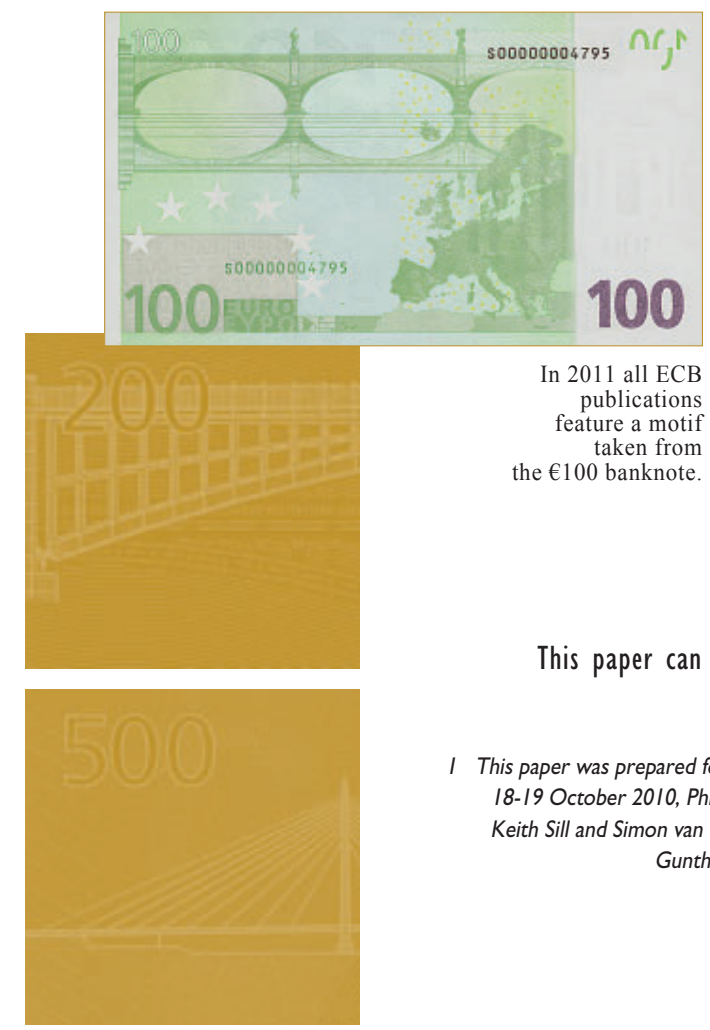

NOTE: This Working Paper should not be reported as representing the views of the European Central Bank (ECB).

The views expressed are those of the author and do not necessarily reflect those of the ECB.

This paper can be downloaded without charge from http://www.ecb.europa.eu or from the Social Science Research Network electronic library at http://ssrn.com/abstract_id $=1881867$. 
(C) European Central Bank, 2011

\section{Address}

Kaiserstrasse 29

60311 Frankfurt am Main, Germany

Postal address

Postfach 160319

60066 Frankfurt am Main, Germany

Telephone

+496913440

Internet

http://www.ecb.europa.eu

Fax

+496913446000

All rights reserved.

Any reproduction, publication and reprint in the form of a different publication, whether printed or produced electronically, in whole or in part, is permitted only with the explicit written authorisation of the ECB or the author.

Information on all of the papers published in the ECB Working Paper Series can be found on the ECB's website, http://www. ecb.europa.eu/pub/scientific/wps/date/ html/index.en.html

ISSN 1725-2806 (online) 


\section{CONTENTS}

Abstract

Non-technical summary

1 Introduction

6

2 Available real-time datasets for fiscal variables

3 Revisions in fiscal data

3.1 Revisions for the government deficit and debt

3.2 Revisions for the cyclically adjusted primary balance

4 Determinants of real-time forecast errors

5 Reaction of fiscal policies to the economic cycle 22

6 Miscellaneous issues

7 Conclusions

References

Tables and figures 


\begin{abstract}
This paper surveys the empirical research on fiscal policy analysis based on real-time data. This literature can be broadly divided in three groups that focus on: (1) the statistical properties of revisions in fiscal data; (2) the political and institutional determinants of projection errors by governments and (3) the reaction of fiscal policies to the business cycle. It emerges that, first, fiscal data revisions are large and initial releases are biased estimates of final values. Second, the presence of strong fiscal rules and institutions leads to relatively more accurate releases of fiscal data and small deviations of fiscal outcomes from government plans. Third, the cyclical stance of fiscal policies is estimated to be more 'counter-cyclical' when real-time data are used instead of ex-post data. Finally, more work is needed for the development of real-time datasets for fiscal policy analysis. In particular, a comprehensive real-time dataset including fiscal variables for industrialized (and possibly developing) countries, published and maintained by central banks or other institutions, is still missing.
\end{abstract}

JEL Classification: E62, H60, H68

Keywords: Fiscal policy, real-time data, data revisions, cyclical sensitivity. 


\section{Non-technical summary}

This paper surveys the empirical research on fiscal policy based on real-time data, i.e., on data available to policymakers when budgetary decisions were taken.

The literature on fiscal policy and real-time data can be divided into three main groups, according to the main focus of each paper. These three groups focus respectively on: (1) the statistical properties of revisions in fiscal data, i.e., on the properties of deviations of ex-post outcomes from current-year estimates and estimates for previous years of fiscal variables; (2) the political and institutional determinants of revisions for current-year estimates and of forecast errors by governments, defined as deviations of ex-post outcomes from governments' fiscal plans for the next year; (3) the evaluation of the ex-ante vs. ex-post cyclical stance of fiscal policies, defined as the reaction of fiscal policies to business cycle fluctuations.

The main findings from this literature are the following. First, revisions in fiscal data tend to be large and can be often predicted based on ex-ante information. Otherwise stated, revisions seem to 'reduce noise' rather than 'add news.' It is also generally found that initial releases by the national statistical authorities are biased estimates of the final values. Second, the presence of strong fiscal rules (establishing, for example, expenditure ceilings) and institutions (such as medium-term budgetary frameworks) tends to be associated with relatively accurate releases of fiscal data and small real-time projection errors by governments and national institutions. Third, more papers now use fiscal plans reported at the time of budgeting for the estimation of fiscal policy reaction functions. In this context, it emerges that the ex-ante reaction of fiscal policies to the economic cycle is found to be more 'counter-cyclical' when real-time data are used - especially as regards the fiscal policy `instrument' - instead of ex-post data.

Regarding the availability of real-time datasets for fiscal policy analysis, more work is needed. In particular, a comprehensive real-time dataset including fiscal variables for industrialized (and possibly developing) countries, published and maintained by central banks or other institutions, is at the current stage still missing. 


\section{Introduction}

Since the seminal work of Orphanides (2001), Croushore and Stark (2001) and Orphanides and van Norden (2002), research employing real-time data has soared in the literature on monetary policy. However, despite the fact that problems related to data revisions and the timeliness of information clearly matter also for fiscal policy, papers on real-time data and fiscal policy analysis have appeared only in recent years. The goal of this paper is to survey this still relatively narrow, but rapidly growing, empirical literature.

The literature on fiscal policy and real-time data can be divided into three main groups, according to the main focus of each paper: (1) the first group includes papers on the statistical properties of revisions in fiscal data, i.e., on the properties of deviations of ex-post outcomes from current-year estimates and estimates for previous years of fiscal variables; (2) the second group focuses on the political and institutional determinants of revisions for current-year estimates and of one-year-ahead forecast errors by governments, defined as deviations of ex-post outcomes from governments' fiscal plans for the next year; ${ }^{1}(3)$ the third group includes papers on the evaluation of the ex-ante vs. ex-post cyclical stance of fiscal policies, i.e., on the reaction of fiscal policies to business cycle fluctuations.

Other papers using real-time data for fiscal policy analysis will not be classified in these three categories, since their main focus is on different issues. For example, papers that propose ways to disentangle the 'automatic' vs. 'discretionary' component of fiscal policy through real-time data and papers on the use of real-time data for the identification of fiscal shocks in structural VAR models are included in this group. These works will be discussed in a separate section at the end of the paper. ${ }^{2}$

\footnotetext{
${ }^{1}$ Part of the real-time fiscal literature overlaps with the literature on fiscal forecasting. A complete overview of the literature on fiscal forecasting is outside the scope of the present work (see Leal, Pérez, Tujula, and Vidal (2008) for an exhaustive survey on the fiscal forecasting literature). Here, only papers on one-year-ahead government fiscal plans (i.e., projections) and on deviations of such plans from ex-post outcomes are considered. In fact, the bulk of budgetary measures for year $t+1$ is approved by governments at the end of year $t$ in their annual budget law. Therefore, one-year-ahead official projections reveal important information on the budgetary stance that authorities plan, in real time, for the following year.

${ }^{2}$ Like any other type of classification, the one proposed in this survey is also arbitrary to some extent. In particular, it can be the case that a single paper addresses different issues. However, an approach that focuses
} 
With few exceptions, the literature on fiscal policy and real-time data has thus far analyzed industrialized countries. Therefore, the survey will focus on this set of countries. Within this literature, most papers have been devoted to the analysis of countries belonging to the European Economic and Monetary Union (EMU) and the European Union (EU), also because European authors have mainly worked in this field. This fact is not surprising, given the stronger interest in Europe in issues related to revisions in fiscal indicators, to fiscal slippages with respect to government plans and to the stance of fiscal policies over the economic cycle.

Indeed, fiscal data reporting plays a central role in the multilateral surveillance framework in Europe, which underpins the EMU with a view of ensuring fiscal discipline in member states. Adherence to the EU's fiscal rules is assessed upon first releases of fiscal data in national accounts terms. ${ }^{3}$ In addition, EU governments' medium-term fiscal plans are regularly monitored by supra-national institutions (i.e., the European Commission and the ECOFIN Council) to ensure that fiscal developments are in line with countries' commitments under the EU's fiscal framework. Therefore, frequent and sizeable revisions of fiscal data - and large deviations of fiscal outcomes from ex-ante plans - may jeopardize the credibility of the EU's surveillance framework. Against this background, the analysis of revisions in fiscal data and of the deviations of fiscal outcomes from governments' plans has attracted much attention in the policy and academic debate in Europe.

The cyclical stance of fiscal policies has also been at the center of the research agenda over recent years, especially in Europe. Again, this can be explained by the adoption of the EU's system of fiscal rules, which define how fiscal policies should behave over certain phases on the main object of interest of each paper has the advantage that it simplifies the overview of the existing literature.

${ }^{3} \mathrm{An}$ important distinction needs to be done regarding the nature of fiscal data. Indeed, fiscal data can be typically recorded according to the 'accrual' (i.e., national account) or 'cash' principle. Accrual data refer to the moment in which the economic transaction, which leads for example to a tax liability, takes place. Cash data refer to the moment in which the Treasury pays government expenditures, or when it receives tax payments. For the same economic transaction, there is generally a time lag between the accrual and the cash flow. In addition, cash data (which are often available at the monthly frequency) are generally not-revised. At the same time, accrual data (typically available at the quarterly or annual frequency) are subject to large revisions. While some interesting papers have recently appeared on the use of cash data for fiscal policy analysis (see, e.g., Onorante, Pedregal, Prez, and Signorini (2010); Hughes-Hallett, Kuhn, and Warmedinger (2010)), this survey focuses on accrual data as these data are predominantly used for the fiscal surveillance process in most countries. 
of the business cycle. ${ }^{4}$ In this context, some commentators have argued that the Stability and Growth Pact (SGP), and in particular the 3\% ceiling on the government deficit-to-GDP ratio, might induce pro-cyclical budgeting during downturns (see, e.g., Eichengreen and Wyplosz (1998)). ${ }^{5}$ Against the normative background of the SGP and the criticisms put forward by some authors on its implications for the cyclical stance of fiscal policies, there has been an increasing interest in investigating how fiscal policies have reacted to the economic cycle, especially since the introduction of the SGP. In particular, some authors have focused on how the reaction of fiscal policies to the economy as planned in real time has differed from what has been observed ex-post, based on revised data.

This paper is close in spirit to the surveys by Croushore (2011) and Golinelli and Momigliano (2009). However, while the former paper covers a vast macroeconomic literature based on realtime data, it does not include papers on fiscal policy. Golinelli and Momigliano (2009) focus on the issue of cyclicality for euro area fiscal policies and review papers based on both ex-post and ex-ante data. The present survey does not include papers based (only) on ex-post data, but it reviews a wider literature on fiscal policy and real-time data. In particular, papers not specifically related to the cyclical stance of fiscal policies are also analyzed. In addition, papers on non-euro-area industrialized countries are also reviewed here.

The main findings from the literature on real-time data and fiscal policy are the following. First, revisions in fiscal data tend to be large and can be often predicted based on ex-ante information; i.e., revisions seem to 'reduce noise' rather than 'add news.' It is also generally found that initial releases by the national statistical authorities are biased estimates of the final values. Second, the presence of strong fiscal rules (establishing, for example, expenditure ceilings) and institutions (such as medium-term budgetary frameworks) tends to be associated

\footnotetext{
${ }^{4}$ In particular, the Stability and Growth Pact recommends that - in order to reach their 'Medium-Term' budgetary objectives of balanced budget positions - EU members states are required to pursue fiscal adjustment efforts that are more ambitious in good economic times than in downturns; i.e., fiscal consolidation should be strongly counter-cyclical during buoyant phases of the economic cycle.

${ }^{5}$ According to this argument, the necessity to abide by the $3 \%$ deficit rule may force governments to cut expenditures and increase taxes during periods in which aggregate demand is already weak.
} 
with relatively accurate current-year estimates of fiscal data and small real-time projection errors by governments and national institutions. Third, more papers now use fiscal plans reported at the time of budgeting for the estimation of fiscal policy reaction functions. In this context, it emerges that the ex-ante reaction of fiscal policies to the economic cycle is found to be more 'counter-cyclical' when real-time data are used - especially as regards the fiscal policy 'instrument' - instead of ex-post data. Finally, it emerges that real-time fiscal data can be used for several other applications related, for example, to the estimation of the 'automatic' vs. 'discretionary' component of fiscal policy, to the testing of predictions from macroeconomic theory, to the analysis of interdependence in fiscal plans, or to the identification of fiscal shocks in structural VAR models.

In general, the survey is structured following a chronological approach, with a view to presenting papers following the time of their first appearance as working papers or monographs. Overall, this survey aims at offering a comprehensive overview of the research in the field of fiscal policy analysis and real-time data. ${ }^{6}$

The rest of the paper is organized as follows. Section 2 is devoted to presenting the available real-time datasets on fiscal variables. In section 3 , the literature on revisions in fiscal data is discussed. Section 4 covers papers on the political and institutional determinants of projection errors. Section 5 is devoted to papers on the cyclical stance of fiscal policies. Section 6 reviews papers on other heterogeneous issues. Finally, section 7 concludes.

\section{Available real-time datasets for fiscal variables}

To the best of the author's knowledge, there are five datasets that include real-time fiscal variables, which are publicly available and constantly updated. Two of these datasets are on the US, one is on the aggregate euro area and on seven single euro area countries (Austria, Belgium, Ireland, Italy, Luxembourg, Spain, the Netherlands), one on the UK, and one on a larger

\footnotetext{
${ }^{6}$ Some papers may have been unintentionally overlooked. In fact, this is a still rather narrow, but rapidly growing, empirical literature. I apologize in advance to the authors for possible omissions.
} 
set of industrialized (OECD) countries. More specifically, the available real-time datasets for the US are the Philadelphia Fed's real-time dataset for macroeconomists ${ }^{7}$ and the St. Louis Fed's ALFRED database. ${ }^{8}$ For the aggregate euro area and single euro area countries, there is the ECB-EABCN's area wide real-time dataset. ${ }^{9}$ For the UK, there is the Bank of England's gross domestic product real-time database. ${ }^{10}$ Finally, there is the OECD's real-time data and revisions dataset, which covers a larger set of industrialized countries. ${ }^{11}$

Focusing on fiscal variables, table 1 summarizes coverage of these five datasets, in terms of countries and variables. The year of the first available vintage is also reported for each variable. The Philadelphia Fed's dataset covers only the US and includes real-time data on real government consumption and investment, at both the federal and state/local level. These data are also published in the St. Louis Fed's ALFRED database, which in addition reports data for the US government's net borrowing (i.e., the government budget deficit) at the federal and state/local level, and its decompostion between total government revenue and expenditure. ${ }^{12}$ Moreover, the St. Louis Fed's dataset is the only one that includes a real-time series for government debt, with vintages starting in 1997. The EABCN's dataset is based on the series published in the ECB's Monthly Bulletin for the aggregate euro area and on data collected by National Central Banks (NCBs) for single euro area countries. ${ }^{13}$ The data frequency is quarterly and annual. Data are published in an updated form each month. Data for the aggregate euro area include the general government deficit, total revenues and expenditures, and government consumption and investment. Data for single euro area countries are generally available only for government consumption. Vintages are available only as of 2001 for the aggregate euro area and for most in-

\footnotetext{
${ }^{7}$ See Croushore and Stark (2001). Data are available at http://www.philadelphiafed.org/research-anddata/real-time-center/real-time-data/.

${ }^{8}$ Data are available at http://alfred.stlouisfed.org/category?cid=1.

${ }^{9}$ See Giannone, Henry, Lalik, and Modugno (2011). Data are available on the EABCN and ECB website at http://sdw.ecb.europa.eu/browse.do?node=4843525 and http://www.eabcn.org/data/rtdb/index.htm.

${ }^{10}$ Data are available at http://www.bankofengland.co.uk/statistics/gdpdatabase/.

${ }^{11}$ Data are available at http://stats.oecd.org/mei/default.asp?rev=1.

${ }^{12}$ The government's net borrowing is equal to the difference between total government revenue and expenditure, which results in a deficit (surplus) if such difference is negative (positive).

${ }^{13}$ Data for the UK are also reported in this dataset, which reflects data published in the Bank of England's gross domestic product real-time database.
} 
dividual countries. For a few countries (e.g., Italy) earlier vintages are also presented. The Bank of England's dataset covers only the UK. It includes quarterly series for the general government net lending, and for government consumption and investment. This dataset spans vintages back to 1990. Finally, the OECD's dataset is based on the 'Main Economic Indicators' publication. It includes real-time data for each OECD country but only for government consumption. For this dataset, the first available vintage differs across countries.

In sum, while the interest in real-time data for fiscal policy analysis has grown over recent years, the publicly available sources still offer a rather limited amount of real-time data for empirical research in the fiscal policy field. In particular, data on European countries are often missing, especially as regards some key fiscal variables such as government debt, government net lending and government cyclically adjusted primary balance. ${ }^{14}$ In addition, most of these publicly available datasets have been published only in recent years. ${ }^{15}$

For these reasons, most of the (especially early) researchers in this field constructed 'ad-hoc' real-time datasets for fiscal variables. Authors often collected real-time data from hard copies of various official publications. Three main sources of data have been used: (1) the OECD Economic Outlook for all industrialized countries; (2) Excessive Deficit Procedure Notifications and (3) Stability and Convergence Programmes for EU countries. The OECD Economic Outlook (EO) is published bi-annually and reports past data, estimates for the current year, and forecasts for one- and two-years-ahead horizons for many fiscal variables (e.g., government balances, government debt, total government revenues and expenditures). Based on past issues of the OECD EO, for example, Golinelli and Momigliano (2006) built a real-time dataset for the government primary balance. Cimadomo (2007) collected real-time series for the general government debt and the cyclically adjusted primary balance, as a measure of the ex-ante or planned cyclical stance.

\footnotetext{
${ }^{14}$ The cyclically adjusted balance is typically defined as a 'structural' balance when one-off and temporary measures are netted out from it. Given that the cyclically adjusted balance and the structural balance tend to be very similar, in the rest of the paper the two terms are used interchangeably.

${ }^{15}$ For example, the OECD real-time database is available as of 2006. The ECB-EABCN real-time database has been available only since 2009 .
} 
Excessive Deficit Procedure (EDP) Notifications data for the general government deficit and debt are published twice per year (in April and October) by the European Commission (Eurostat), which collects and validates data reported by single EU member states. EDP data comprise figures for the current year $t$, forecasts for year $t+1$ and past data. Figures back to year $t-4$ are subject to revision in each EDP release. EDP data have a key role in the context of the EU fiscal surveillance framework. In fact, based on these data, and according to the provisions of the SGP, the European Council may decide to initiate an 'Excessive Deficit Procedure' against the countries that have deviated from the reference value of a government deficit of $3 \%$ of GDP in the base year $t$, and whose deficit is not expected to be corrected over a given forecast horizon. ${ }^{16}$ An example of a paper using EDP Notifications data is de Castro, Pérez, and Rodríguez (2011), which analyzed the statistical properties of revisions for deficit figures for several EU countries.

The third main sources of real-time data are the annual updates of the EU's Stability and Convergence programmes. Under the provisions of the 'preventive arm' of the SGP, euro-area member states are indeed requested to prepare annual stability programmes and other EU member states are requested to prepare convergence programmes and submit them to the European Commission and the ECOFIN Council by the end of each year. ${ }^{17}$ Stability and Convergence programmes report figures for the past year, current-year estimates and projections up to year $t+3$ for several fiscal indicators including the general government budget balance and debt, the cyclically adjusted balance, total government revenues and expenditure. The programmes are scrutinized and assessed by the European Commission and the ECOFIN Council to detect budgetary imbalances that could imply risks for fiscal sustainability. The aim is to ensure rigorous budgetary discipline through surveillance and coordination of budgetary policies within the euro area and EU. Based on this source, for example, Holm-Hadulla, Hauptmeier, and Rother

\footnotetext{
${ }^{16}$ For a more detailed description of the EU fiscal framework see, e.g., Morris, Ongena, and Schuknecht (2006).

${ }^{17}$ As of 2011, programmes will be submitted to the Ecofin council by the end of March, in the context of the so-called 'European semester'. The European semester is one of the first initiatives that emerged from a task force chaired by the president of the European Council, Herman Van Rompuy, with a view to strengthening European provisions on economic governance.
} 
(2011) constructed a real-time dataset for government expenditure for EU countries.

Finally, other authors used alternative sources. For example, Loukoianova, Vahey, and Wakerly (2003) - one of the first papers to carry out fiscal policy analysis with real-time data - employed a real-time dataset for the US government primary balance which was collected by the authors based on another official publication, the 'Economic Report of the US President.' For the Netherlands, Beetsma, Giuliodori, Walschot, and Wierts (2010) collected fiscal plans released by the Dutch Ministry of Finance and reported in annual budget laws.

\section{Revisions in fiscal data}

This section reviews the first group of papers, which focus on the statistical properties of revisions in fiscal data. To facilitate the discussion, the following notation will be used. Let $f$ denote a generic fiscal variable, for example, the government budget balance. Let $f_{t \mid v}$ be the value of $f$ for time $t$ released by the government or a statistical agency in vintage $v$. Fiscal variables are typically reported at quarterly or annual frequency (see also table 1). Therefore, $t$ will refer to a certain quarter or a year. Instead, the frequency of data releases can be monthly, quarterly, semi-annual or annual. ${ }^{18}$ As discussed below, most of the empirical research on revisions in fiscal data focuses on annual data, released annually or semi-annually. ${ }^{19}$ The notation $f_{t \mid T}$ refers to the final or 'true' value for $f$, which is released at the end of the observation period (i.e., at time $T)$. The term 'first release' is generally used to refer to data for year $t$ published at the end of year $t$ or at the beginning of year $t+1$. The following identity will hold

$$
f_{t \mid T} \equiv f_{t \mid v}+u_{t \mid v}^{f}
$$

where $u_{t \mid v}^{f}$ is the revision between the final vintage $T$ and $v \cdot{ }^{20}$ If $v=t, f_{t \mid t}$ is the current-year

\footnotetext{
${ }^{18}$ For example, the EABCN dataset reports quarterly data for aggregate euro area fiscal variables. Data are collected each month from the ECB Monthly Bulletin and therefore reported at the monthly frequency.

${ }^{19}$ This is the case of research based on data from the OECD Economic Outlook, from EDP deficit notifications or from Stability and Convergence Programmes for EU countries.

${ }^{20}$ The real-time literature sometimes refers to $u^{f}$ as a 'revision error' (see, e.g., Orphanides and van Norden
} 
estimate (i.e., "nowcast") of $f$ and $u_{t \mid t}^{f}$ its revision. If $v>t, f_{t \mid v}$ is a release of past data for $f$ and $u_{t \mid v}^{f}$ the related revision. If $v<t, f_{t \mid v}$ is a forecast for $f$ and $u_{t \mid v}^{f}$ will be the related forecast error. When $v=t-1, u_{t \mid v}^{f}$ is the one-year-ahead forecast error. ${ }^{21}$

One of the main differences between the one-year-ahead forecast error and revisions for the current year or past years is that the forecast error can be affected by new fiscal measures that are announced and implemented after the cut-off date of the forecast. Clearly, this source of errors will not affect the estimates for the past years or the current year, especially if the latter are produced at the end of the year. In this case, all fiscal measures will be included in the information set of the statistician at the time of the data release.

In the following, the literature on revisions for the main fiscal variables - namely, the government deficit, debt and the cyclically-adjusted deficit - is reviewed. ${ }^{22}$

\subsection{Revisions for the government deficit and debt}

The literature shows that data revisions for the general government deficit and debt are often very large. Figure 1, taken from de Castro, Pérez, and Rodríguez (2011), displays subsequent revisions for the general government budget balance in Greece, over the period 1999-2009. Numbers are sometimes striking. Revisions amount to more than 3 percentage points of GDP in years 20002003 and at the end of the sample. For example, in only six months, between April and October 2009, the government budget balance reported by Greek authorities to Eurostat for 2008 was revised downward from $-5 \%$ of GDP to around -8\% of GDP. Revisions for the 2009 figure (not shown) were even more impressive, with the estimated 2009 balance plunging from -3\% of GDP

(2002) and Giannone, Reichlin, and Small (2005)). In this paper, the terms 'revision' and 'revision error' will be used interchangeably.

${ }^{21}$ Estimates for the same year are sometimes referred to as "forecasts" (see, e.g., Pina and Venes (2011)). Here, the term "current-year estimates" is used to distinguish the estimates for the same year from the "one-year-ahead" forecasts. The related errors are therefore also defined as "revisions".

${ }^{22}$ One additional important fiscal variable is government consumption. The latter is computed as the sum of compensation of public employees, intermediate consumption and other minor components (e.g. social transfers in kind). While government consumption is a relevant fiscal variable - given that it is a component of GDP - there is little literature on revisions to this indicator. Exceptions are Kholodilin and Siliverstovs (2009), ller and Hansson (2004) and Sleeman (2006) who analyze the properties of revisions for government consumption for, respectively, Germany, Sweden and New Zealand. All the three papers show that revisions to government consumption explain an important share of revisions to GDP for these three countries. 
to more than -10\% of GDP between the April 2009 release and following releases. The Greek case is certainly extreme, but sizeable revisions have also been recorded in other cases. For example, Figure 2a shows - for the aggregate euro area and for the period 1998-2009 - the official currentyear estimate for the government budget balance in addition to government forecasts for years $t+1, t+2$ and $t+3$. Data are based on national Stability and Convergence programmes published by euro area governments at the end of each year. It clearly emerges that, on average, currentyear estimates (and projections) reported by euro area governments often differ significantly from actual outcomes. In the period 1998-2003 this was mainly due to revenue shortfalls, given that real-time estimates of government revenues turned out to be in general overly optimistic (see Figure 2c). For the last period, slippages were mainly explained by government expenditure being estimated ex-ante to be lower than what was observed ex-post (see Figure 2b).

One of the earlier works on the analysis of revisions in fiscal data is Gordo-Mora and Nogueira-Martins (2007). The authors follow a descriptive approach to study deficit and debt figures reported in EDP Notifications by 14 EU countries to Eurostat since 1994 and for the period 1990-2005. It emerges that France, Germany and the United Kingdom reported the most reliable deficit/surplus figures over this period. Denmark, Portugal, Luxembourg and Sweden are the countries that had the largest dispersion of revisions. It is also shown that for several countries, notably Germany, Spain, Luxembourg, Italy and Portugal, data on the yearly changes in debt have been more reliable than those on the deficit. Finally, the authors find no evidence of differences in revision patterns before and after the methodological shift from the European System of Accounts (ESA) 79 to ESA 95, which occurred in 2000.

Balassone, Franco, and Zotteri (2007) and von Hagen and Wolff (2006) focus on revisions to first releases of deficit data for some EU countries and on a comparison between the government deficit and changes in government debt, i.e., the so-called deficit-debt or stock-flow adjustment. Both papers suggest that stock-flow adjustments have been used strategically by EU governments to meet the $3 \%$ deficit threshold in real-time. This resulted in opportunistic accounting that 
often yielded to an ex-ante underestimation of the budget deficits. In particular, von Hagen and Wolff (2006) find that the practice of hiding budget deficit deteriorations through stock-flow adjustments is especially strong in times of recession, as the cost of restrictive policies tends to be larger in these phases of the business cycle.

The statistical properties of revisions in deficit figures are analyzed by de Castro, Pérez, and Rodríguez (2011) based on an approach similar to one proposed by Croushore and Stark (2001) and Aruoba (2008). The paper focuses on 15 EU countries and uses data from EDP Notifications. The dataset is constructed based on past vintages of EDP data from spring 1999 to autumn 2009, covering the period 1995-2008. Results indicate that revisions of deficit data are frequent and are characterized by a negative bias: final releases tend to display lower surpluses or higher deficits than initial notifications, although dispersion among and within countries seems to be large. In addition, it is shown that revisions in government balance figures, rather than being primarily caused by revisions in GDP figures, embed a systematic and important fiscal component. Finally, the analysis suggests that revisions in government deficit data seem to reduce noise, rather than adding news, given that such revisions are correlated with ex-ante information and can be predicted. ${ }^{23}$

The finding that revisions to fiscal data tend to reduce noise, rather than adding news, emerges also in Garratt and Vahey (2006) for a study on the UK. Based on the quarterly real-time dataset constructed for the UK by Castle and Ellis (2002) and spanning the period 1961Q3-1999Q2, the authors characterize the relationships between preliminary and subsequent measurements for 16 commonly used UK macroeconomic indicators, including government expenditure. They show that revisions for UK government expenditure tend to have zero mean but a mean absolute value larger than GDP. Also in this case, revisions appear to be predictable on the basis of ex-ante information.

\footnotetext{
${ }^{23}$ As discussed in Croushore (2011), data revisions are typically described as adding news or reducing noise. If data revisions contain news, it means they are not predictable on the basis of the information set held by the statistician at the time of the data release, i.e. $u_{t \mid v}^{f} \perp f_{t \mid v}$. If data revisions reduce noise, they can be correlated with the ex-ante information set but they are orthogonal to the final release, i.e. $u_{t \mid v}^{f} \perp f_{t \mid T}$.
} 
As regards revisions to the government debt-to-GDP ratio, Cimadomo (2007) shows that based on a dataset for 19 OECD countries over the period 1995-2006 - the debt ratio reported by the OECD at the end of year $t$ for the same year is often remarkably different from what was observed at the end of the sample, due to errors in measurement but also to possible changes in accounting rules (see column 4 of table 2). ${ }^{24}$ Revisions to this indicator are the largest for high debt countries such as Greece and Japan but also for Norway.

\subsection{Revisions for the cyclically adjusted primary balance}

The cyclically adjusted balance $(C A B)$ and cyclically adjusted primary balance $(C A P B)$ are typically used in empirical research to capture the 'discretionary' component of fiscal policy (see, e.g., Galí and Perotti (2003)). The $C A B$ is computed as the difference between the nominal balance and its automatic or cyclical component, which is assumed to be independent from government interventions (within the same year). The $C A B$ is typically estimated as a function of the output gap. It therefore incorporates three main sources of uncertainty: the nominal output, the potential output, and the headline nominal deficit. The $C A P B$ is equal to the $C A B$ minus interest payments.

In Cimadomo (2007), I provide evidence on the size of revisions for the current-year estimate and the one-year-ahead forecast of the $C A P B$, and for the current-year estimate of the government debt and the output gap, based on data reported in the OECD EO. Table 2 - taken from that paper - shows that countries for which the output gap has been poorly measured tend to also display large revisions and forecast errors for the $C A P B$ (see, e.g., Italy, Portugal and Japan).

The $C A B$ also has a key role in the EU fiscal surveillance framework. ${ }^{25}$ The use of the

\footnotetext{
${ }^{24}$ For example, a change in the statistical definition of general government gross debt (government gross financial liabilities) for Canada occurred in 2002. Before 2002, funded government employees' pension liabilities were included in government gross debt, whereas these have been netted out by the OECD starting from 2002 to ensure consistency with other countries.

${ }^{25}$ Under the reformed Stability and Growth Pact, which entered into force in 2005, EU member states are requested to present their country-specific 'medium-term objective (MTO)' for the government budget balance in their annual stability or convergence programme. Such medium-term objectives are defined in cyclically adjusted and net of one-off and other temporary factors. In addition, the SGP states that member states that have not
} 
$C A B$ as a real-time fiscal surveillance tool for EU countries is investigated in Larch and Turrini (2010) and Hughes-Hallett, Kattai, and Lewis (2011). Larch and Turrini (2010) highlights that the performance of this indicator has been overall disappointing, given that - especially due to errors in measuring the cyclical position in real time - the $C A B$ did not always provide accurate signals of member states' fiscal performance. Hughes-Hallett, Kattai, and Lewis (2011) questions the use of cyclically-adjusted indicators as surveillance tools in early-warning systems. This is due to difficulties in providing accurate estimates of cyclically-adjusted indicators in real-time. In particular, the authors find that around half of the real-time errors in cyclically adjusted balances can be attributed to revisions in the cyclical component of the budget balance, and the other half to revisions in the deficit-to-GDP ratio across vintages.

\section{Determinants of real-time forecast errors}

This section reviews papers on the political and institutional determinants underlying revisions for current-year estimates (or nowcasts) and one-year-ahead forecast errors by governments. Revisions for current-year releases of fiscal data are generally driven by methodological improvements and by updates in the data sources. Deviations of fiscal outcomes from government plans are mainly influenced by forecast errors, due to model uncertainty or unexpected shocks. ${ }^{26}$ However, in some cases, and in particular for what concerns the government budget balance, inaccurate releases of data for the current year - and biased projections for future years - may be the consequence of political interference in the production of statistics. This is the case es-

yet achieved their MTOs are expected to take steps to do so over the cycle. To this end, euro area and ERM II member states should, as a benchmark, pursue an annual adjustment in cyclically adjusted terms, net of one-off and temporary measures, of $0.5 \%$ of GDP (see also Morris, Ongena, and Schuknecht (2006)).

${ }^{26}$ Cebotari, Davis, Lusinyan, Mati, Mauro, Petrie, and Velloso (2009) investigates some sources of deviations of outcomes from government plans for the government debt, based on a large panel of developed and developing countries. The paper shows that an important role in accounting for such deviations is attributable to exchange rate fluctuations and contingent liabilities. The former channel suggests that an unexpected exchange rate depreciation tends to increase significantly the real value of public debt, if the share of debt in foreign currency is sizeable. The latter channel is related to obligations triggered by an uncertain event, which include both explicit liabilities, i.e. those defined by law or contract (e.g. debt guarantees) and implicit liabilities, i.e. moral or expected obligations for the government, based on public expectations or pressures (e.g. bailouts of banks or public sector entities). 
pecially in Europe, given that adherence to the EU's system of fiscal rules is judged based on first releases of data and projections for the next year for the general government deficit. This may eventually lead to creative accounting and fiscal gimmickry by governments and national statistical agencies, with the goal of meeting the SGP requirements in real time. In this context, it is often shown that the presence of strong fiscal rules and institutions tends to be associated with more accurate releases of fiscal data and fiscal projections by governments.

The literature has devoted considerable attention to studying the determinants of one-yearahead government forecast errors and, to a lesser extent, revisions to current-year estimates and estimates for past years. The approach generally followed consists in the estimation of a relation similar to

$$
u_{t \mid v}^{f}=\Theta X_{t \mid t}+\epsilon
$$

where $u_{t \mid v}^{f}$ is the revision for the current year (or past years) for $f$ (if $v \geq t$ ) or the one-yearahead forecast error (if $v=t-1$ ), where $X_{t \mid t}$ represents a set of ex-ante explanatory variables with $\Theta$ the associated vector of coefficients, and where $\epsilon$ is a residual component. The vector $X_{t \mid t}$ typically includes political and institutional variables such as the government's political orientation or a fiscal rule index.

One of the earlier works on the performance of budgetary projections by EU member states - and on the political and institutional determinants of the related forecast errors - is Strauch, Hallerberg, and von Hagen (2004). ${ }^{27}$ Based on Stability and Convergence programmes presented by EU governments over the period 1991-2002, the authors show that forecasts exhibit different patterns of accuracy and biases across countries. ${ }^{28}$ In addition, the authors show that the form of fiscal governance is an important determinant of biases in budgetary forecasts: forecasts

\footnotetext{
${ }^{27}$ Other previous papers have been devoted to fiscal forecasting issues (see in particular Artis and Marcellino (2001)). However, the political and institutional determinants of forecasting errors are generally not investigated in these papers.

${ }^{28}$ In particular, according to the paper, few countries predicted actual developments rather well (Denmark, Sweden, the UK and partly the Netherlands). Other countries tended to report optimistic forecasts compared to outcomes over this time period. Germany, France, Italy, Portugal and Greece fall into this latter group.
} 
are more cautious in delegation, contract and mixed governance structures than in fragmented systems.

Brück and Stephan (2006) analyze the determinants of one-year-ahead forecast errors for the general government deficit for a panel of 15 euro area countries plus Japan and the US, for the period 1995-2003. The data sources are the spring and autumn European Commission's forecasts. The paper shows that, since the adoption of the SGP in 1999, euro area governments have manipulated deficit forecasts before elections. The paper finds that the political orientation affects the quality of forecasts: governments moving to the right (left) tend to make more pessimistic (optimistic) forecasts. In addition, it emerges that minority governments in euro area countries tend to make overly optimistic forecasts.

The role of fiscal institutions and fiscal governance for the accuracy of current-year fiscal projections by EU governments is also investigated by Pina and Venes (2011) based, in this case, on data from EDP Notifications for the period 1994-2006. The authors show that currentyear estimates for the government deficit are affected by fiscal institutions and by opportunistic motivations, especially since the SGP came into force in 1999. In particular, they find that upcoming elections tend to induce over-optimism. In addition, they show that commitment or mixed forms of fiscal governance and the presence of numerical expenditure rules - which introduce ceilings on expenditure growth each year - are associated with greater prudence.

Jonung and Larch (2006) focus on a different dimension, i.e., on the 'strategic' use of real GDP growth forecasts by EU governments for their fiscal projections. They show that, at the EU level, there is a tendency to overestimate the underlying rate of growth of the economy - and therefore to underestimate budget deficits - at the moment of preparing the budget. To address this problem, the authors suggest that GDP forecasting should be assigned to an authority independent from the government. Then, the government would be obliged to adopt these forecasts in preparing the official budget.

A somewhat different conclusion is reached by Moulin and Wierts (2006). The authors claim 
that, in the EU, the failure to achieve the projected reductions in the general government deficit primarily reflects difficulties in adhering to expenditure plans in nominal terms. However, this does not seem to be due to particularly unfavorable macroeconomic developments, compared to overly optimistic ex-ante GDP forecasts. As a consequence, the paper points to a need for strengthening expenditure control mechanisms in most of the EU member states.

The relation between fiscal governance and fiscal forecasts is inspected by von Hagen (2010), using current-year estimates and one-year-ahead projections reported in Stability and Convergence Programmes for the period 1998-2004. The paper shows that, within the fiscal framework of the EMU, a trade-off exists between delegation on the one hand and contracts and strong rules on the other. Governments operating under contracts and strong rules appear to be more cautious in their projections than governments operating under delegation. At the same time, governments operating under delegation are shown to be able to react more effectively to unforeseen economic and fiscal developments.

Beetsma, Giuliodori, and Wierts (2009) focus on the 'implementation phase' of the budget process. The authors analyze the determinants of governments' one-year-ahead forecast errors for the government deficit defined as deviations of the end-of-the-year budget from budget plans reported in the EU's Stability and Convergence Programmes at the end of the year before. Using a dataset of EU countries for the period 1998-2007, they show that ambitious fiscal plans and their implementation benefit from stronger national fiscal institutions. This latter finding is also highlighted in Beetsma, Bluhm, Giuliodori, and Wierts (2011), who focus on deviations of expost budget outcomes from the end-of-the-year budget. This paper finds that an improvement in the quality of institutions reduces the degree of optimism at the first-release stage, thereby making first-release figures more informative about the final outcomes.

Beetsma, Giuliodori, Walschot, and Wierts (2010) explore fiscal planning and budget implementation in the Netherlands, using a real-time dataset from the annual budget over the period 1958-2009. The paper shows that, for the Netherlands, planned balances are on average 
unbiased, although they are overoptimistic during the first half of the sample and too pessimistic during the second half of the sample. The paper underlines that institutional factors play an important in explaining cautious fiscal planning. In particular, it is highlighted that the recent regime of the 'trend-based budget policy' has worked well for fiscal discipline in the Netherlands.

Finally, to the best of the author's knowledge, de Castro, Pérez, and Rodríguez (2011) is the only existing paper on the determinants of revisions for past releases of the general government deficit. The authors show that political cycles help to explain revision patterns, with governments tending to hide deficits in electoral and pre-electoral years and when the economic conditions were unfavorable.

To sum up, the main findings from this strand of literature are that: (1) one-year-ahead government fiscal projections - as well as releases of fiscal data for the current year or past years - tend to be affected by political and institutional factors. In particular, the presence of numerical fiscal rules (for example, establishing tight expenditure ceilings) and of strong fiscal institutions (such as medium-term budgetary frameworks) is generally associated with more accurate data releases and fiscal forecasts; (2) the form of fiscal governance matters, as fiscal projections tend to be more cautious in contract or delegation governance structures than in fragmented systems and (3) upcoming political elections are often found to induce over-optimism in fiscal projections.

\section{Reaction of fiscal policies to the economic cycle}

A growing number of studies have been devoted to investigating the cyclical stance of fiscal policies using ex-post data and, more recently, real-time data. The underlying idea is to test whether fiscal policies have exerted a stabilizing influence on the business cycle (i.e., have they been 'counter-cyclical'), or whether they have tended to exacerbate economic fluctuations (i.e., have they been 'pro-cyclical'). Earlier studies based on ex-post data tend to indicate that, in industrialized countries, the cyclical stance of fiscal policies appears to be predominantly 
acyclical or pro-cyclical; i.e., taxes are increased (decreased) and public expenditure decreased (increased) during economic downturns (upturns). ${ }^{29}$ The new real-time literature incorporates ex-ante data for the estimation of fiscal policy reaction functions similar to

$$
f_{t \mid v}=\alpha+\beta y_{t \mid v}+\Gamma X_{t \mid v}+\epsilon
$$

where $f$ represents a fiscal policy indicator, $y$ a business cycle indicator, $X$ a vector of other possible control variables and $\epsilon$ is a residual component. As before, the subscript $t$ is the reference year and $v$ the relevant vintage. Ex-post data are typically denoted by the subscript $t \mid T$ or $t+1 \mid T$, where $T$ represents the last available vintage. Real-time data are described by the subscript $t \mid t$ or $t+1 \mid t$ indicating, respectively, the current-year estimate and the one-year-ahead real-time forecast of the concerned variable. In this context, $f_{t+1 \mid t}$ is fiscal stance planned at the time of budgeting for the following year and $y_{t+1 \mid t}$ are the expected cyclical conditions.

Within this literature, many papers focus on the reaction of discretionary fiscal policy to economic fluctuations. Hence, $f$ is typically represented by the cyclically adjusted government (primary) balance. Other papers focus on overall fiscal policy, which includes both an automatic component (through the so-called 'automatic stabilizers') and discretionary fiscal measures. The output gap is generally used as a business cycle indicator. The vector $X$ typically includes the government debt and a larger set of variables thought to influence fiscal policies. For example, $X$ often includes a dummy variable for election years.

Authors have introduced real-time information for the estimation of fiscal policy reaction functions in various steps. The first paper to estimate a fiscal policy reaction function based on real-time data is Forni and Momigliano (2005). The paper uses real-time observations only for the output gap and ex-post observations for all the other variables. Following the notation described above, the fiscal reaction function here includes $f_{t+1 \mid T}, y_{t+1 \mid t}, X_{t \mid T}$. The idea under-

\footnotetext{
${ }^{29}$ See, for example, Lane (2003a), Lane (2003b), European Commission (2004) and Cimadomo (2005). See also Corsetti, Meier, and Müller (2010) for an analysis on OECD countries based on ex-post data, pointing to acyclicality of government spending for most of the countries considered.
} 
lying this approach is that the government has full control of its budgetary policies. Thus, what matters is the actual stance of fiscal policy, which in this context is represented by the ex-post structural balance $f_{t \mid T}$. Based on a panel of 19 OECD countries over the period 1993-2003, and on real-time values for the output gap collected from past issues of the OECD EO, the results indicate a counter-cyclical stance during economic slowdowns. ${ }^{30}$

Golinelli and Momigliano (2006) also focus on the actual fiscal policy stance for euro area countries over the period 1994-2008. Therefore, their dependent variable - as in Forni and Momigliano (2005) - is $f_{t+1 \mid T}$. However, they include a larger set of factors that may have influenced the fiscal stance. Among these explanatory factors are two real-time variables: the output gap and the previous-year government balance budget. As for the other explanatory variables - which include an index for European fiscal rules and the debt ratio - they use expost observations. Their estimates indicate that discretionary fiscal policies have reacted in a stabilizing and symmetrical manner to the business cycle; i.e., there is no significant difference in the behavior of fiscal policy in recessions and expansions.

The use of ex-ante 'fiscal plans' released at the time of budgeting for the estimation of the ex-ante fiscal policy stance is introduced by Cimadomo (2007). ${ }^{31}$ The underlying idea is that ex-ante fiscal plans by governments may be significantly different from ex-post outcomes. ${ }^{32}$ In fact, the implementation of fiscal measures is typically characterized by a high degree of uncertainty. This depends on the long and often unpredictable time lags between budgetary decisions and the execution of the budget, which policymakers cannot fully control. In addition, governments have inaccurate estimates of the state of the economy in real-time, and therefore of its impact on budget balances through the automatic stabilizers. Hence, the proposed empirical

\footnotetext{
${ }^{30}$ See also Marinheiro (2008) for a similar approach, but based on real-time data for the output gap from the European Commission, for the period 1999-2006.

${ }^{31}$ See Cimadomo (2011) for an updated version.

${ }^{32}$ This issue is not relevant for monetary policy. In fact, under normal circumstances, central banks can control their operating instruments with great accuracy. In particular, short-term interest rates are subject to negligible revisions, and just for a few days after the first release of data. On the contrary, fiscal indicators incorporate different sources of uncertainty related in particular to the real-time estimate of output and of the execution of the budget.
} 
analysis is based on ex-ante projections for the cyclically adjusted budget balance (i.e., $f_{t+1 \mid t}$ ) to capture discretionary fiscal measures planned ex-ante by fiscal policymakers. In general, this is the first paper that uses ex-ante observations for all variables included in the fiscal policy rule (i.e., $f_{t+1 \mid t}, y_{t+1 \mid t}, X_{t \mid t}$ ), with the view of fully replicating the information set available to policymakers at the time budgetary decisions were made. Using a dataset of 19 OECD countries constructed from past issues of the OECD EO for the period 1994-2006, the paper finds that governments in industrialized countries plan counter-cyclical fiscal policies, especially during times of expansions. ${ }^{33}$

The idea of using fiscal plans for the estimation of fiscal policy reactions has been subsequently adopted by other papers. Some of these papers also focus on the cyclical stance of fiscal policies (e.g., Lewis (2009), Beetsma and Giuliodori (2010), Pina (2009), Holm-Hadulla, Hauptmeier, and Rother (2011)); some other papers address different issues (e.g., Giuliodori and Beetsma (2008)).

Lewis (2009) investigates the cyclical stance and effect of EU accession for fiscal policy in Central and Eastern European countries (CEECs). The paper uses a real-time dataset constructed from the Transition Report of the European Bank for Reconstruction and Development (EBRD). Fiscal policy rules similar to (2) are estimated where, however, the total ex-ante government budget balance - which therefore also includes the effects of automatic stabilizers - is employed as a fiscal policy indicator. It is found that in CEECs budget balances react in a stabilizing way to economic activity, and they are less inert than is typically found in Western Europe. In addition, there is evidence of a fiscal loosening in the run-up to EU accession. ${ }^{34}$

\footnotetext{
${ }^{33}$ The paper also shows that the bias arising from the use of ex-post data for the estimation of the ex-ante fiscal stance can be predicted based on second-order moments of ex-ante data and data revisions.

${ }^{34}$ Lewis (2009) is included in this review, although not all CEECs are considered as mature market economies. As regards developing countries, few papers have used real-time data for fiscal policy analysis. One exception is Lledó and Poplawski-Ribeiro (2011), which uses real-time data to estimate fiscal rules for sub-Saharan African countries. The paper shows that fiscal policy implementation gaps in this group of countries tend to be on average comparable to other regions of the world. As in other regions, planned fiscal consolidations tend to be less ambitious than anticipated and in some cases end in fiscal expansions. In addition, it is found that revenue shortfalls account for the bulk of fiscal balance implementation gaps among oil exporters, overspending seems to dominate in middle-income countries, while a combination of both accounts for higher deficits or lower surpluses than planned among low-income countries.
} 
Beetsma and Giuliodori (2010) explore how fiscal policies in the OECD have responded to unexpected information about the economy during the period 1995-2006. In particular, the authors first estimate fiscal rules using ex-ante data for all variables, as in Cimadomo (2007). Then, they assess how fiscal policy reacts to new information, especially about the business cycle. They find that there are marked differences between ex-ante behavior of fiscal policies and responses to new information, as well as between fiscal policy of the EU countries and the other OECD countries. In particular, the EU countries react in a pro-cyclical way to unexpected changes in the output gap, while the responses of the other OECD countries are acyclical.

Budgetary plans reported in the European Commissions autumn forecasts are used by Pina (2009) to estimate fiscal reaction functions with ex-post and real-time data. In a panel of 15 EU countries from 1987 to 2006, the paper confirms the finding that moving from plans to final data generally weakens the counter-cyclicality of budget balances. In addition, the paper shows that this is especially true for government expenditure, though not for revenues. Finally, and similarly to Beetsma and Giuliodori (2010), this work analyzes deviations from plans during budget implementation. It is shown that updates in fiscal plans during the implementation phase are often driven by electoral opportunism.

The impact of numerical expenditure rules on the propensity of governments to deviate from expenditure targets in response to surprises in cyclical conditions is explored by Holm-Hadulla, Hauptmeier, and Rother (2011). The paper starts from the consideration that, due to political fragmentation in the budgetary process, expenditure policy might be prone to a pro-cyclical bias. However, this tendency may be mitigated by numerical expenditure rules. These hypotheses are tested against data from the EU's Stability and Convergence Programmes. Results suggest that deviations between actual and planned government expenditure are positively related to unanticipated changes in the output gap; i.e., they are indeed pro-cyclical. However, it is found that numerical expenditure rules indeed reduce this pro-cyclical bias. Moreover, the pro-cyclical spending bias is found to be particularly pronounced for spending items with a high degree of 
budgetary flexibility, such as subsidies and government investment.

Barrios and Rizza (2010) focus on a different dimension, i.e., on the size and the determinants of unexpected changes in EU countries' tax revenues and their impact on the ability of EU governments to use fiscal policy as a macroeconomic stabilization device. Tax revenue surprises are defined as differences between government plans (as reported in EU stability programmes) and ex-post outcomes. The paper finds that countries that have experienced the largest tax revenue windfalls in the run-up to the 2008/2009 crisis have also tended to run more pro-cyclical fiscal policies. These results tend to indicate that while tax revenue windfalls may be good for the public purse during favorable times, they may also (paradoxically) lessen the ability of the countries concerned to run countercyclical fiscal policies when cyclical conditions revert.

Finally, Golinelli and Momigliano (2009) propose a survey on the cyclical sensitivity of fiscal policies, which covers papers based on both ex-post and ex-ante data. They show that different results from this literature can be ascribed to different modeling choices and data vintages. From a methodological point of view, they make a case for the use of the standard modeling approach where the discretionary component of fiscal policy is estimated through the use of cyclically adjusted primary balances.

\section{$6 \quad$ Miscellaneous issues}

This section is devoted to reviewing papers that used real-time fiscal data but that investigated - as their main focus - issues not specifically related to the analysis of data revisions or the cyclical stance of fiscal policies.

Test of Barro's tax smoothing hypothesis. Loukoianova, Vahey, and Wakerly (2003) is one of the first papers to introduce real-time data for fiscal policy analysis. The authors construct a real-time dataset for the US government primary balance based on the 'Economic Report of the President' as a complement to the Philadelphia Fed's real-time dataset. The results indicate that a tax smoothing approach, augmented by fiscal habit considerations, provides an accurate 
description of US budget balance movements. These findings are shown to be robust to the use of ex-post or real-time data for the budget balance.

Definition of discretionary vs. automatic fiscal policy. The idea that automatic stabilizers may depend on actual GDP, while discretionary fiscal policy depend on the information that policy makers have in real-time, is explored by von Kalckreuth and Wolff (2011). The authors assume that the ex-ante information set of policymakers includes GDP data released in real time. Actual GDP is approximated using the last GDP release. Then, the authors compute a real-time measurement error on output. According to this approach, discretionary fiscal policy can be expected to react to measurement error on output, whereas automatic fiscal policy will not. This identification approach is adopted to test the central identifying assumption of the seminal structural VAR by Blanchard and Perotti (2002). It is found that that government expenditure is adjusted upward if GDP in real-time is lower than true GDP.

A similar approach is adopted by Bernoth, Hughes-Hallett, and Lewis (2008), where the actual stance of fiscal policy, measured in this context by the ex-post primary balance $f_{t+1 \mid T}$ in equation (3), is supposed to react to the ex-post output gap $y_{t+1 \mid T}$ and to the measurement error made in the real-time evaluation of the output gap. The paper also builds on the assumption that discretionary fiscal policy responds to the real-time output gap while automatic stabilizers react to the ex-post output level. Based on a panel of 14 OECD countries, the paper finds lower estimates of the automatic fiscal responses and stronger (and more counter-cyclical) estimates of the discretionary responses to the output gap.

In relation to these two papers, Darby and Mélitz (2011) propose an approach to simultaneously estimate the automatic and discretionary response of fiscal policy to the cycle, based on the assumption that the automatic fiscal reaction to the cycle occurs more quickly (i.e. within the same year) than discretionary fiscal policy. The analysis is based on a panel of 20 OECD countries for the period 1981-2003. The estimation of fiscal policy reaction functions, including real-time and ex-post values of the output gap, indicates stronger stabilization properties of the 
government balance than found in the existing literature. This finding is explained by a stabilizing reaction of several expenditure (including social) items to the cycle - which is generally neglected in the existing literature (see also Darby and Mélitz (2008)).

Interdependence of fiscal policy plans. The interdependence of fiscal policy plans in the EU countries is investigated in Giuliodori and Beetsma (2008). The authors first estimate a fiscal policy rule based on ex-ante data for all variables. Then, they augment the set of control variables with (an average of) ex-ante plans reported by neighboring EU countries. The idea is that fiscal plans might be interdependent for a variety of reasons, such as direct externalities due to crossborder public investments, yardstick competition, tax competition and peer pressure among governments. Results point to empirical evidence of fiscal policy interdependence. However, the interdependence is rather asymmetrically distributed: the fiscal plans of the large countries affect the fiscal plans of the small countries, but not vice versa.

Identification of government spending shocks in sVAR models. Finally, Cimadomo, Hauptmeier, and Sola (2011) employ real-time data for US government spending to identify two different types of government spending shocks: (1) spending shocks that are accompanied by an expected reversal of public spending growth and (2) spending shocks that are accompanied by expectations of further spending growth. The paper shows that shocks associated with an expected spending reversal exert expansionary effects on the economy and accelerate the reduction of public debt. At the same time, shocks associated with a further expected increase in spending tend to be characterized by a contraction in aggregate demand and a more persistent increase in public debt.

\section{Conclusions}

While the empirical research on fiscal policy based on real-time data is still relatively narrow, it has rapidly grown over recent years. This paper surveys this literature. Three main areas of research are identified, which focus respectively on: (1) the statistical properties of revisions in 
fiscal data; (2) the political and institutional determinants of data revisions and one-year-ahead forecast errors and (3) the stance of fiscal policies over the economic cycle.

As regards the first set of papers, it emerges that revisions in fiscal data tend to be large and can often be predicted based on ex-ante information; i.e., revisions seem to 'reduce noise' rather than 'add news.' In addition, initial releases by the national statistical authorities are biased estimates of the final values. Most papers in the second group show that strong fiscal rules (for example, establishing tight expenditure ceilings) and institutions (such as mediumterm budgetary frameworks) tend to lead to relatively accurate releases of fiscal data and small deviations of fiscal outcomes from governments' plans. As regards the third set of papers, it emerges that fiscal plans reported at the time of budgeting are now more frequently used to capture the ex-ante stance of fiscal policy. In this context, the ex-ante reaction of fiscal policies to the economic cycle is estimated to be more 'counter-cyclical' when real-time data are used instead of ex-post data.

Looking ahead, the publication and maintenance by central banks and international institutions of datasets including key real-time fiscal indicators are fundamental preconditions for the future development of this strand of empirical research.

\section{References}

Artis, M., And M. Marcellino (2001): "Fiscal Forecasting: The Track Record of the IMF, OECD and EC," Econometrics Journal, 4(1), 20-36.

Aruoba, S. B. (2008): "Data Revisions Are Not Well Behaved," Journal of Money, Credit and Banking, 40(2-3), 319-340.

Balassone, F., D. Franco, and S. Zotteri (2007): "The Reliability of EMU Fiscal Indicators: Risks and Safeguards," Temi di discussione (Economic working papers) 633, Bank of Italy, Economic Research Department.

Barrios, S., and P. Rizza (2010): "Unexpected Changes in Tax Revenues and the Stabil- 
isation Function of Fiscal Policy. Evidence for EU," European economy - economic papers, Directorate General Economic and Monetary Affairs, European Commission.

Beetsma, R., B. Bluhm, M. Giuliodori, and P. Wierts (2011): "From First-Release to Ex-Post Fiscal Data: Exploring the Sources of Revision Errors in the EU," CEPR Discussion Papers 8413.

Beetsma, R., And M. Giuliodori (2010): "Fiscal Adjustment to Cyclical Developments in the OECD: An Empirical Analysis Based on Real-Time Data," Oxford Economic Papers, $62(3), 419-441$.

Beetsma, R., M. Giuliodori, M. Walschot, and P. Wierts (2010): "Fifty Years of Fiscal Planning and Implementation in the Netherlands," CEPR Discussion Papers 7969.

Beetsma, R., M. Giuliodori, and P. Wierts (2009): "Planning to Cheat: EU Fiscal Policy in Real Time," Economic Policy, 24, 753-804.

Bernoth, K., A. Hughes-Hallett, and J. Lewis (2008): "Did Fiscal Policy Makers Know What They Were Doing? Reassessing Fiscal Policy with Real Time Data," CEPR Discussion Papers No. 6758

Blanchard, O., and R. Perotti (2002): "An Empirical Characterization of the Dynamic Effects of Changes in Government Spending and Taxes on Output," Quarterly Journal of Economics, 117(4), 1329-1368.

BrüCK, T., And A. Stephan (2006): "Do Eurozone Countries Cheat with their Budget Deficit Forecasts?," Kyklos, 59(1), 3-15.

Castle, J., and C. Ellis (2002): "Building a Real-Time Database for GDP(E)," Open Access publications from University of Oxford.

Cebotari, A., J. Davis, L. Lusinyan, A. Mati, P. Mauro, M. Petrie, and R. Velloso (2009): "Fiscal Risks: Sources, Disclosure, and Management," International Monetary Fund.

Cimadomo, J. (2005): "Has the Stability and Growth Pact Made Fiscal Policy More ProCyclical?," La Lettre du CEPII, (247).

(2007): "Fiscal Policy in Real Time," Working Paper No. 07-10, CEPII.

(2011): "Fiscal Policy in Real Time," Scandinavian Journal of Economics, forthcoming. 
Cimadomo, J., S. Hauptmeier, and S. Sola (2011): "Identifying the Effects of Government Spending Shocks with and without Expected Reversal: An Approach Based on Real-Time Data," Working Paper Series 1361, European Central Bank.

Corsetti, G., A. Meier, And G. Müller (2010): "What Determines Government Spending Multipliers?," mimeo.

Croushore, D. (2011): "Frontiers of Real-Time Data Analysis," Journal of Economic Literature, $49,72-100$.

Croushore, D., and T. Stark (2001): "A Real-Time Data Set for Macroeconomists," Journal of Econometrics, 105(1), 111-130.

Darby, J., And J. MÉLitz (2008): "Social Spending and Automatic Stabilizers in the OECD," Economic Policy, 23, 715-756.

(2011): "Joint Estimates of Automatic and Discretionary Fiscal Policy: The OECD 1981-2003," CEPII Working Paper No. 11-14.

de Castro, F., J. J. Pérez, and M. Rodríguez (2011): "Fiscal Data Revisions in Europe," Banco de Espana Working Paper No. 1106.

Eichengreen, B., and C. Wyplosz (1998): "The Stability Pact: More Than a Minor Nuisance?," Economic Policy, 13(26), 65-113.

European Commission (2004): "The Pro-Cyclicality of Fiscal Policy in EMU," in Quarterly Report on the Euro Area, vol. 3.

Forni, L., And S. Momigliano (2005): "Cyclical Sensitivity of Fiscal Policies Based on RealTime Data," Applied Economics Querterly, 50(3), 299-326.

Galí, J., And R. Perotti (2003): "Fiscal Policy and Monetary Integration in Europe," Economic Policy, 18(37), 533-572.

Garratt, A., and S. P. Vahey (2006): "UK Real-Time Macro Data Characteristics," Economic Journal, 116(509), 119-135.

Giannone, D., J. Henry, M. Lalik, and M. Modugno (2011): "An Area-Wide Real-Time Database for the Euro Area," Review of Economics and Statistics, forthcoming.

Giannone, D., L. Reichlin, and D. Small (2005): "Nowcasting GDP and Inflation: The Real-Time Informational Content of Macroeconomic Data Releases," Finance and Economics Discussion Series 2005-42, Board of Governors of the Federal Reserve System (U.S.). 
Giuliodori, M., and R. Beetsma (2008): "On the Relationship between Fiscal Plans in the European Union: An Empirical Analysis Based on Real-Time Data," Journal of Comparative Economics, 36(2), 221-242.

Golinelli, R., and S. Momigliano (2006): "Real-Time Determinants of Fiscal Policies in the Euro Area," Journal of Policy Modeling, 28(9), 943-964.

(2009): "The Cyclical Reaction of Fiscal Policies in the Euro Area: The Role of Modelling Choices and Data Vintages," Fiscal Studies, 30(1), 39-72.

Gordo-Mora, L., and J. Nogueira-Martins (2007): "How Reliable are the Statistics for the Stability and Growth Pact?," European Economy - Economic Papers 273, Directorate General Economic and Monetary Affairs, European Commission.

Holm-Hadulla, F., S. Hauptmeier, and P. Rother (2011): "The Impact of Numerical Expenditure Rules on Budgetary Discipline over the Cycle," Applied Economics, forthcoming.

Hughes-Hallett, A., R. Kattai, and J. Lewis (2011): "How Reliable are CyclicallyAdjusted Balances in Real Time?," Contemporary Economic Policy, forthcoming.

Hughes-Hallett, A., M. Kuhn, and T. Warmedinger (2010): "The Gains from Early Intervention in Europe: Fiscal Surveillance and Fiscal Planning Using Cash Data," Working Paper Series 1220, European Central Bank.

Jonung, L., And M. Larch (2006): "Improving Fiscal Policy in the EU: The Case for Independent Forecasts," Economic Policy, 21(47), 491-534.

Kholodilin, K. A., And B. Siliverstovs (2009): "Do Forecasters Inform or Reassure? Evaluation of the German Real-Time Data," Applied Economics Quarterly, 55(4), 269-294.

Lane, P. R. (2003a): "Business Cycles and Macroeconomic Policy in Emerging Market Economies," International Finance, 6(1), 89-108.

L (2003b): "The Cyclical Behaviour of Fiscal Policy: Evidence from the OECD," Journal of Public Economics, 87(12), 2661-2675.

LArch, M., And A. Turrini (2010): "The Cyclically Adjusted Budget Balance in EU Fiscal Policymaking," Intereconomics: Review of European Economic Policy, 45(1), 48-60.

Leal, T., J. J. PÉrez, M. Tujula, and J.-P. Vidal (2008): "Fiscal Forecasting: Lessons from the Literature and Challenges," Fiscal Studies, 29(3), 347-386. 
Lewis, J. (2009): "Fiscal Policy in Central and Eastern Europe with Real Time Data: Cyclicality, Inertia and the Role of EU Accession," DNB Working Papers 214, Netherlands Central Bank, Research Department.

Lledó, V., And M. Poplawski-Ribeiro (2011): "Fiscal Policy Implementation in SubSaharan Africa," IMF Working Paper, forthcoming.

LleR, L.-E., And K.-G. Hansson (2004): "Revision of National Accounts: Swedish Expenditure Accounts and GDP," Journal of Business Cycle Measurement and Analysis, 2004(3), 19.

Loukoianova, E., S. P. Vahey, and E. C. Wakerly (2003): "A Real Time Tax Smoothing Based Fiscal Policy Rule," Computing in Economics and Finance No. 118, Society for Computational Economics.

Marinheiro, C. (2008): "The Stability and Growth Pact, Fiscal Policy Institutions and Stabilization in Europe," International Economics and Economic Policy, 5(1), 189-207.

Morris, R., H. Ongena, and L. Schuknecht (2006): "The Reform and Implementation of the Stability and Growth Pact," Occasional Paper Series 47, European Central Bank.

Moulin, L., And P. Wierts (2006): "How Credible Are Multiannual Budgetary Plans in the EU?," in Fiscal Indicators, proceedings of the 8th Banca d'Italia Workshop on Public Finance.

Onorante, L., D. J. Pedregal, J. J. Prez, and S. Signorini (2010): "The Usefulness of Infra-Annual Government Cash Budgetary Data for Fiscal Forecasting in the Euro Area," Journal of Policy Modeling, 32(1), 98-119.

Orphanides, A. (2001): "Monetary Policy Rules Based on Real-Time Data," American Economic Review, 91(4), 964-985.

Orphanides, A., and S. van Norden (2002): "The Unreliability of Output Gap Estimates in Real Time," Review of Economics and Statistics, 84, 569-583.

PinA, A. (2009): "Elusive Counter-Cyclicality and Deliberate Opportunism? Fiscal Policy from Plans to Final Outcomes," Working Paper No. w200906, Banco de Portugal, Economics and Research Department.

Pina, A., And N. Venes (2011): "The Political Economy of EDP Fiscal Forecasts: An Empirical Assessment," European Journal of Political Economy, forthcoming. 
Sleeman, C. (2006): "Analysis of Revisions to Quarterly GDP - a Real-Time Database," Reserve Bank of New Zealand Bulletin, 69.

Strauch, R., M. Hallerberg, and J. von Hagen (2004): "Budgetary Forecasts in Europe - the Track Record of Stability and Convergence Programmes," Working Paper Series No. 307, European Central Bank.

von Hagen, J. (2010): "Sticking to Fiscal Plans: The Role of Institutions," Public Choice, $144(3), 487-503$.

von Hagen, J., And G. B. Wolff (2006): "What Do Deficits Tell Us About Debt? Empirical Evidence on Creative Accounting With Fiscal Rules in the EU," Journal of Banking \& Finance, 30(12), 3259-3279.

von Kalckreuth, U., and G. B. Wolff (2011): "Identifying Discretionary Fiscal Policy Reactions with Real-Time Data," Journal of Money, Credit and Banking, forthcoming. 


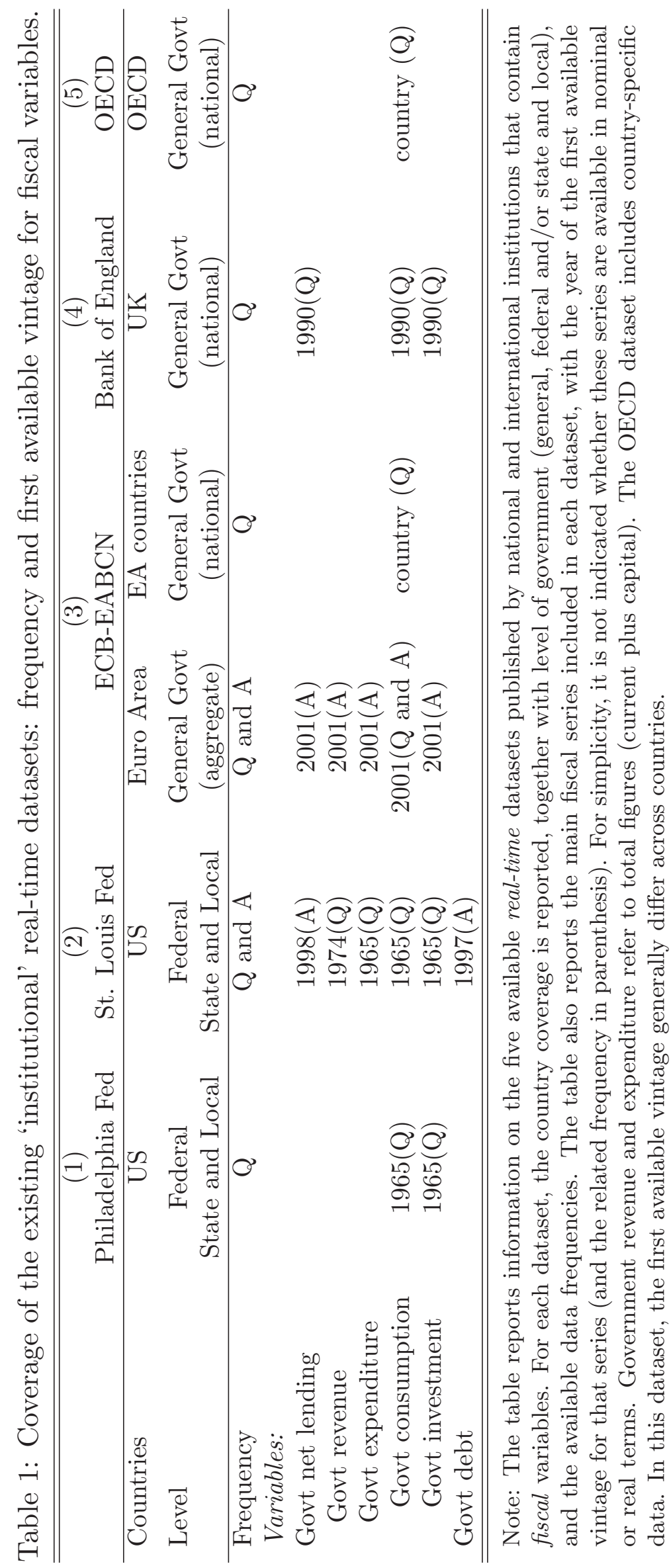


Table 2: Mean absolute value of revisions and of one-year-ahead forecast errors.

\begin{tabular}{lcccr}
\hline \hline & $(1)$ & $(2)$ & $(3)$ & $(4)$ \\
& $u_{t \mid t}^{g a p}$ & $u_{t \mid t-1}^{c a p b}$ & $u_{t \mid t}^{c a p b}$ & $u_{t \mid t}^{\text {debt }}$ \\
\hline Germany & 1.15 & 1.12 & 0.76 & 2.34 \\
Belgium & 0.68 & 0.64 & 0.46 & 3.40 \\
Austria & 1.13 & 0.79 & 0.97 & 3.85 \\
Finland & 2.51 & 1.25 & 1.30 & 5.38 \\
Spain & 0.66 & 0.58 & 0.77 & 3.83 \\
Greece & 0.73 & 2.94 & 2.83 & 13.59 \\
Ireland & 1.61 & 2.12 & 1.44 & 4.39 \\
Italy & 1.82 & 1.82 & 1.44 & 6.55 \\
France & 0.58 & 0.67 & 0.62 & 2.22 \\
Netherlands & 0.76 & 1.20 & 1.15 & 6.95 \\
Portugal & 1.30 & 1.56 & 1.56 & 4.63 \\
Sweden & 1.20 & 1.72 & 1.19 & 4.70 \\
Denmark & 0.75 & 1.18 & 0.96 & 6.19 \\
UK & 0.81 & 1.26 & 0.75 & 6.33 \\
Norway & 1.23 & 2.77 & 2.49 & 9.16 \\
US & 1.18 & 1.65 & 0.71 & 4.25 \\
Canada & 0.80 & 1.21 & 0.88 & 5.19 \\
Japan & 2.18 & 1.51 & 1.25 & 11.82 \\
Australia & 0.78 & 1.18 & 1.08 & 2.95 \\
Mean & 1.15 & 1.43 & 1.19 & 5.73 \\
\hline \hline
\end{tabular}

Source: Cimadomo (2007). Calculations are based on the December editions of the OECD Economic Outlook, from Number 56 (1994) to 80 (2006).

Notes: $u_{t \mid t}^{g a p}, u_{t \mid t}^{c a p b}, u_{t \mid t}^{d e b t}$ is the revision for the current-year estimate of, respectively, the output gap, the cyclically adjusted primary balance and public debt. $u_{t \mid t-1}^{c a p b}$ is the error for the one-year-ahead forecast of the cyclically adjusted primary balance (see equation 1 ). 


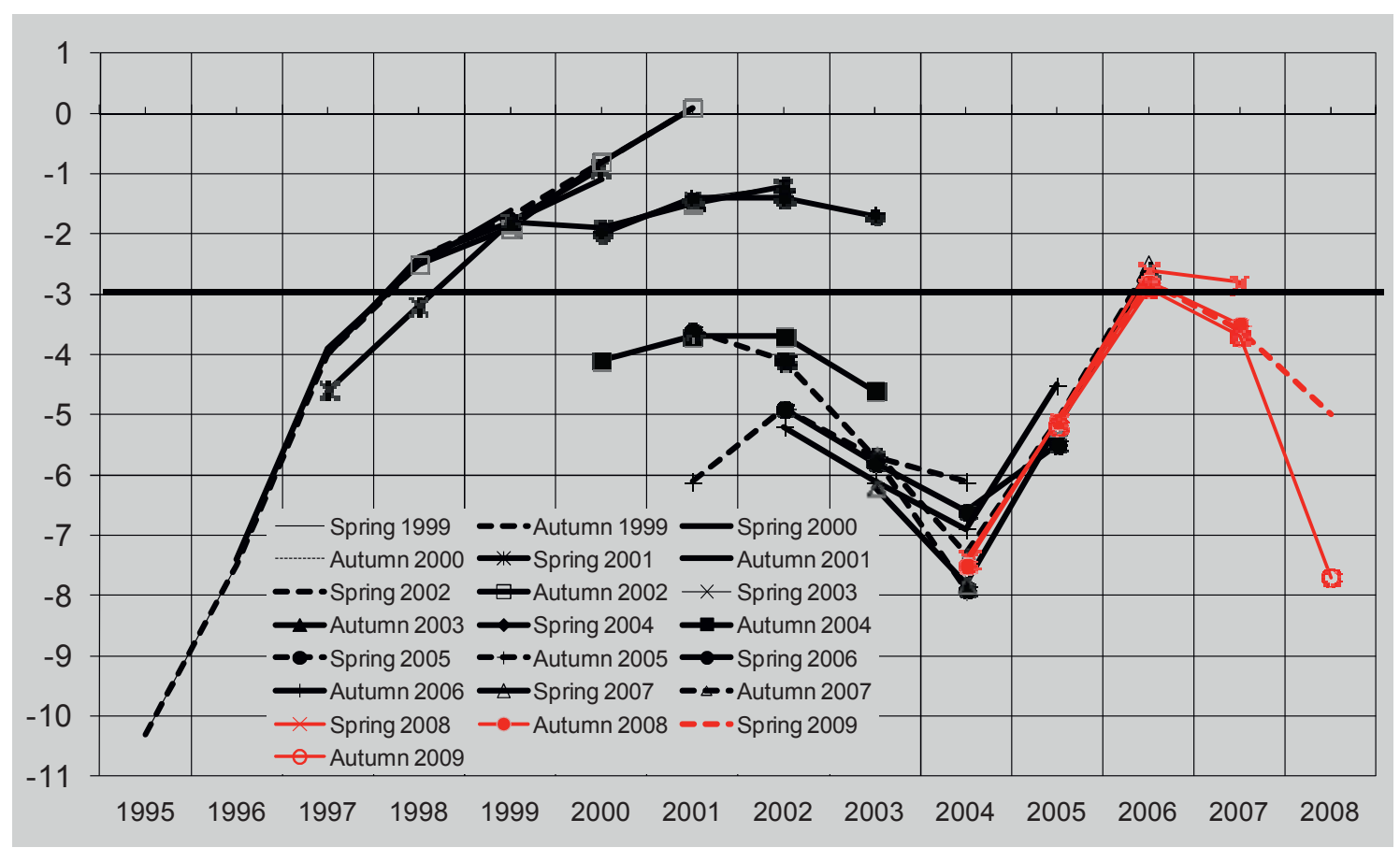

Figure 1: Successive releases of data for the general government budget balance (in \% of GDP) for Greece as reported by Eurostat in the context of the spring and autumn Excessive Deficit Procedure (EDP) Notifications. Source: de Castro, Pérez and Rodríguez (2011). 
Figure 2a: Euro area government budget balance

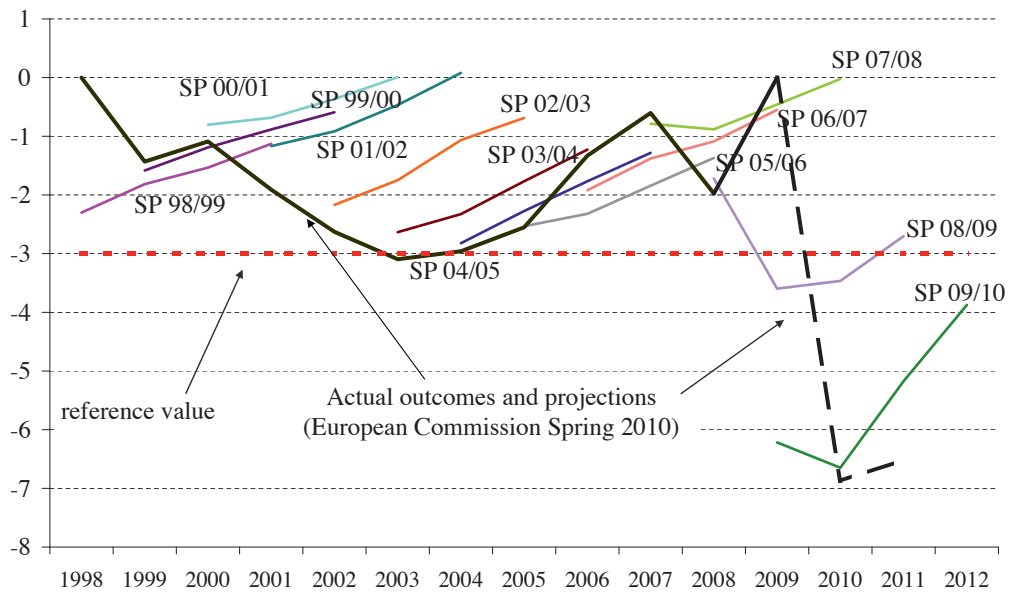

Figure 2b: Euro area government expenditures

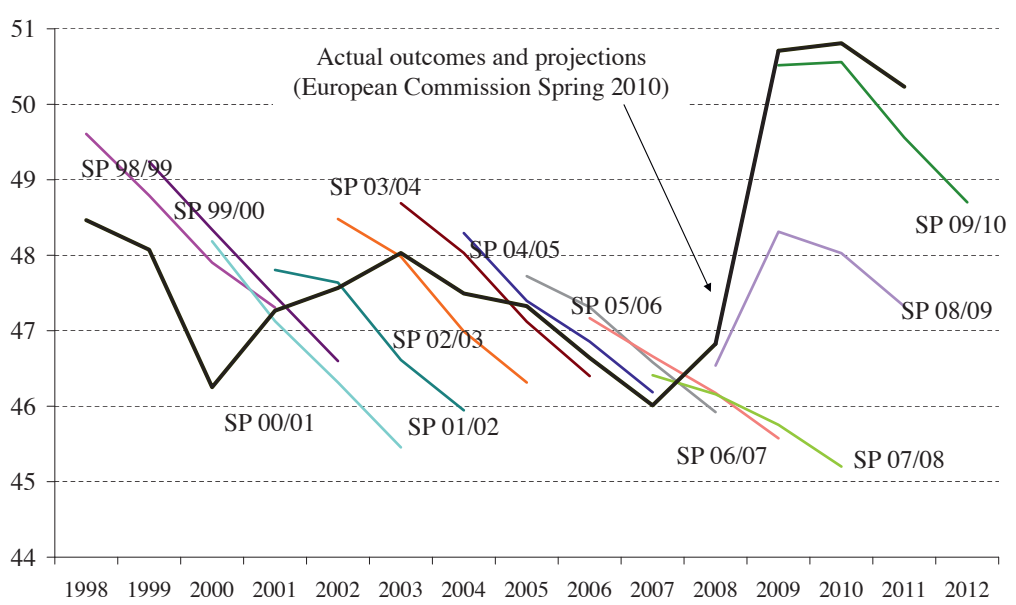

Figure 2c: Euro area government revenues

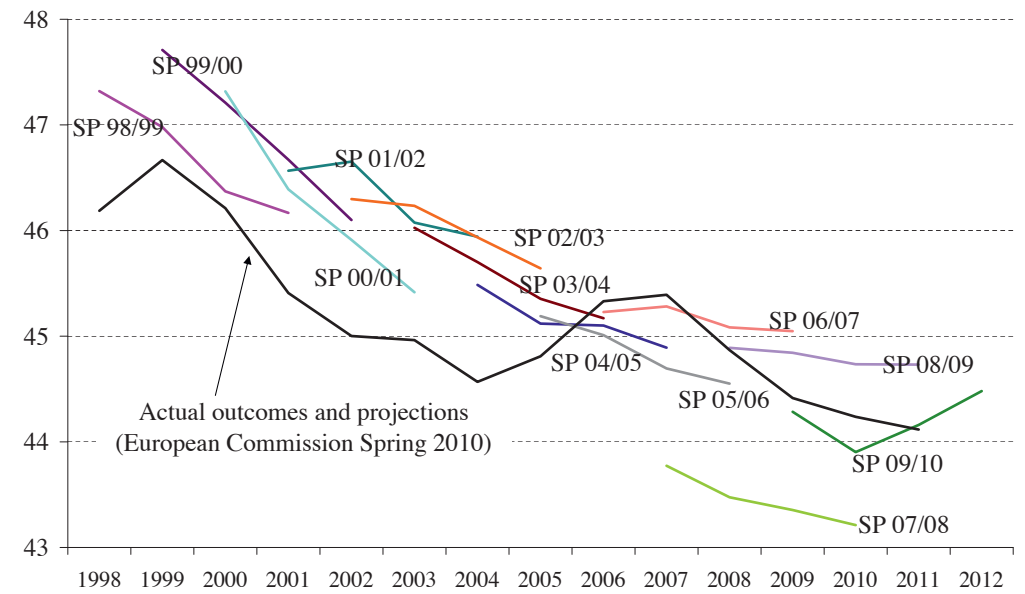

Figure 2: Current-year estimates and projections for years $t+1, t+2$ and $t+3$ for the general government budget balance, general government expenditures and revenues (all in percentage of GDP) for the aggregate euro area. Estimates and projections are taken from successive stability programmes (SP) updates, from 1998/1999 to 2009/2010. Actual outcomes (black-solid lines) are from the European Commission spring 2010 forecasts. 
